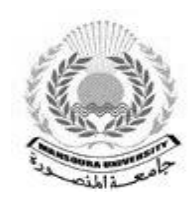

Mansoura University

Faculty of Tourism and Hotels

\title{
THE CENTRAL ROLE OF WHITE LINEN IN ANCIENT EGYPTIAN WOMEN'S DRESSES \& FASHION
}

\author{
By \\ Dr/ Rasha Kamel Soleman
}

Ass.Prof of Ancient Egyptian Archaeology-College of Archaeology and

Tourism- Misr University For Science and Technology

\section{Abstract}

The examination of artistic representations of women's costume throughout the ancient Egyptian era reveals a notion of style, taste, and appealing expression. In the ancient Near East, Egypt was well known for its weaving of linen cloth as it was valued at such a high level that labourers received lengths of textiles in return for their work and offerings of fine linen were given to temples. This celebrated feature of ancient Egyptian society continues to carry significance as depictions of ancient Egyptian women in dresses remain prized pieces of museum collections. As the garments themselves have mostly deteriorated with time, the modern researcher is mostly left with artistic representations of dresses from various periods of ancient Egyptian history, but not necessarily with the intention of creating chronological timeline of women's costume by dynasty. Though styles are shared between periods, exemplary examples of the use of linen within different styles of dress have been chosen to represent the artistic character of the age and the evolution of the ancient woman's signature garment. 


\section{Keywords}

Women, white linen, clothing, dresses, and adornment.

\section{الدور الرئيسي للكتان الأبيض في فساتين وأزيلاء المرأة المصرية القديمة}

إن فحص التصوير الفني لملابس النساء طوال عصر الاسرات المصرية القديمة

يكثف مفهوم الأسلوب والذوق والتعبير الجذاب للمرأة المصرية القديمة. ِِّ الشرق الأدنى القديه، كانت مصر مشهورة بنسيجها من الكتان حيث كانت تُقدر على جودة الهول

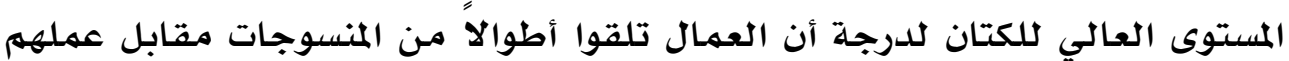
وتقديم قرابين من الكتان الناعم للمعابد. لا تزال هذه الميزة الشهيرة للمجتهمع المصري

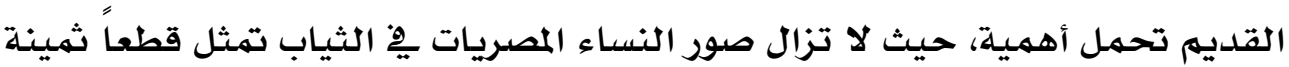
من مجموعات المتاحف. بما أن الملابس نفسها تدهورت يِّ معظمها بمرور الوقت، فإن الباحثة لجاءت إلى التمثيلات الفنية لفساتين من فترات مختلفة من التاريخ المصري

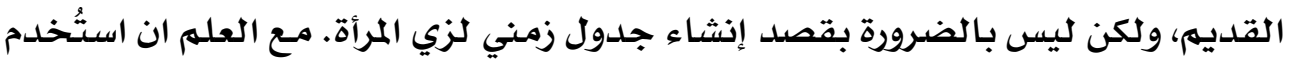
نفس الطراز ِِّ فترات عديدة، فقد تم اختيار أمثلة مثالية لاستخدام الكتان ِِْ أنماط مختلفة من اللباس لتمثيل الطابع الفني للعصر وتطور ثياب المرأة القديمة.

\section{The central role of White Linen in} Ancient Egyptian Women's dresses \& Fashion

\section{Introduction}

The role of linen in the ancient Egyptian society was immensely important. Linen was so central because of its wide diverse of function - it was used for clothing, bedding1, nets for animals, or even sails of a ship2. Egypt was famous in the ancient Near East for their practice of weaving linen cloth and for its production goods. Linen cloth was an essential component of ancient Egyptian everyday life. The majority of textiles were made from flax. Any cloth made from the latter plant fiber is defined as linen.3 
The process of preparing flax seeds for linen production included several stages; three of which are most important to note. Firstly, sowing the flax seeds occurred after the annual flooding of the Nile by mid- November. Next, the flax seeds were harvested; they took approximately three months to mature. Thus, it was crucial for the seeds to be pulled out at the right time once they reached maturity. Finally, the flax seed heads were removed either by hand or by a long plank, where the seeds fell into a pile around the base of the plank.

Nevertheless, the scope of this paper does not extend beyond clothing. The above mentioned intricate, meticulous process of flax production was key in maintaining clothing style, which revolved around linen. Tradition was essential to ancient Egyptians - life and religion were completely interlaced - and this was reflected in self- representation, like clothing. Clothing styles did not change much, and when new garments were introduced into the fashion, they were worn with older, more traditional garments. Due to the extreme heat of the weather, clothing had two consistent attributes: it was roomy and light. Linen was also most commonly used for clothes because it was flexible, producing clothing that was neither heavy, nor hot, it could be draped over the body simply, and it was easy to launder.

The stunning, elaborate costumes that one normally attributes to ancient Egyptian clothing style should be replaced by historical reality: the white linen schenti - a man's loincloth, or shendyt - kilt and the kalasiris - the long, close fitting sheath dress worn mainly by women, among other simple garments worn at the time. 4

\section{Societal Values Concerning White linen}

White, Hdj was associated with pureness, supremacy, peace, happiness, death, and mourning. Thus, white perceived the notions of reincarnation5. The most important element of white color is the ancient Egyptians day and its brightness. It was the 
colour commonly used in the ancient Egyptian wardrobe, although this was partly for practical reasons. Plain white linen was preferred over other colours during most Egyptian era. In fact, to increase the whiteness of the linen, the fabric was exposed to the intense desert sun to bleach it. The popularity of white linen in ancient Egypt is striking because most people would assume that it was a rare sighting in daily life. Furthermore, the centrality of white linen is compelling because it enabled experimentation with decoration and embellishment that would not have been as necessary if the linen was a more vibrant colour. For instance, white fabric could more easily be hand painted with various figures

and hieroglyphs. 6 Thus, the presence of white linen in ancient Egypt furthers an exploration of self-expression in the simplest forms, and how this self-expression was compared with more highly decorated clothing and costume. This comparison could have taken place on one person's body, clothed in white linen along with other embellishments, or in among different people, where an unadorned outfit was preferred versus a very adorned outfit.

\section{Fabrics}

Before examining the depiction of women's dresses in ancient Egyptian art, it is necessary to discuss the variety of fabrics and the process of textile making. Nearly all ancient Egyptian clothing was made of linen. Herodotus, writing in the fifth century, is responsible for the previously held misconception that this was because of the ancient Egyptians' religious aversion to wool.7 He falsely noted how, "noting of wool is taken into their temples or buried with them for their religion forbade it."8 However, Rosalind M.H. Janssen's 1995 research documents that wool from sheep and goats were used in both funerary and domestic contexts. Though this evidence asserts the use of animal-derived textiles and disapproves 
Herodotus' observation, the use of fabrics other than linen was much less common. Janssen notes how wool would likely only be used for warm clothing, especially shawls. 9As an ancient Egyptian would not often need a warm shawl in the region's climate, light, breathable fabrics were better suited for the desert environment. Essentially, linen was the most used textile because it was made from the widely available flax plant and was comfortable in the warm climate. Non-linen plant-based textiles made from grass, reed, and hemp were occasionally used, however, evidence of linen weaving from the Neolithic period circa 5000 BCE proves how linen remained the dominant material from its earliest presence onward.10

\section{Production of Linen}

The production of linen was elaborate and required the labour of many skilled workers. Tomb decoration and miniature models depict stages of the process and remain the primary source for research into ancient Egyptian textile production. Flax was planted in the late fall after the inundation of the Nile and took roughly three months to mature. Depending on when the plant was pulled, flax produced fibers that would produce either closer woven textile with a finer texture or coarse, stronger fibers to be used for rope or utilitarian purposes. The tomb of Paheri11, dating back to the reign of Tuthmosis III at El Kab (EK-3) depicts the agricultural process from planting to harvest and namely shows both men and women pulling flax and binding it into bundles (Plate 1). 12 


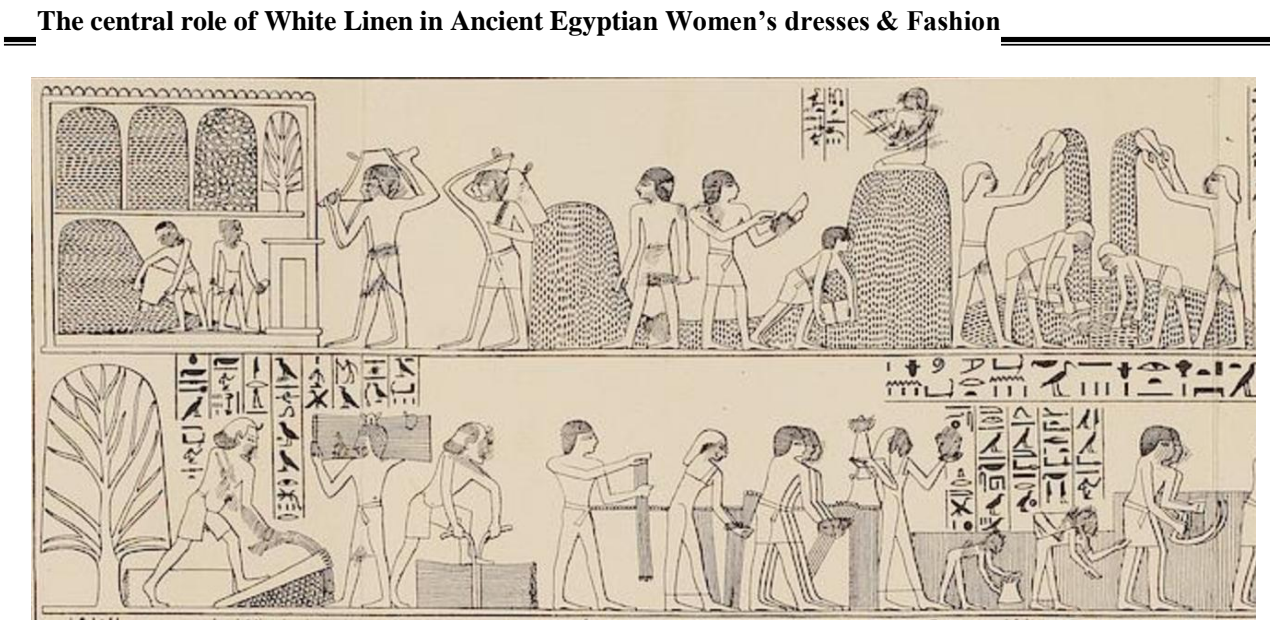

(Plate 1) Agricultural scenes from the 18th Dynasty tomb of Paheri at El Kab.13

After pulling, the flax is then dried, de-seeded, soaked and beaten before being spun into thread.14 No depictions of the spinning process are found until the Middle Kingdom, wherein three different methods are shown.15

A model from the Middle Kingdom tomb of Meketre shows a busy weaving16 workshop with female workers spinning the thread with spindles as their coworkers weave a section of cloth - a pile of linen fabrics in the corner show how hard they had been working (fig. 1). Like the figurines, ancient craftspeople would have used either horizontal or vertical looms. A bowl depicting a horizontal loom found in a pre-dynastic tomb in Lower Egypt demonstrates how long standing the practice of horizontal loom weaving was in ancient Egypt.17 However, it was not until the New Kingdom that the vertical loom was introduced, likely from the Near East during the Hyksos occupation. 18 


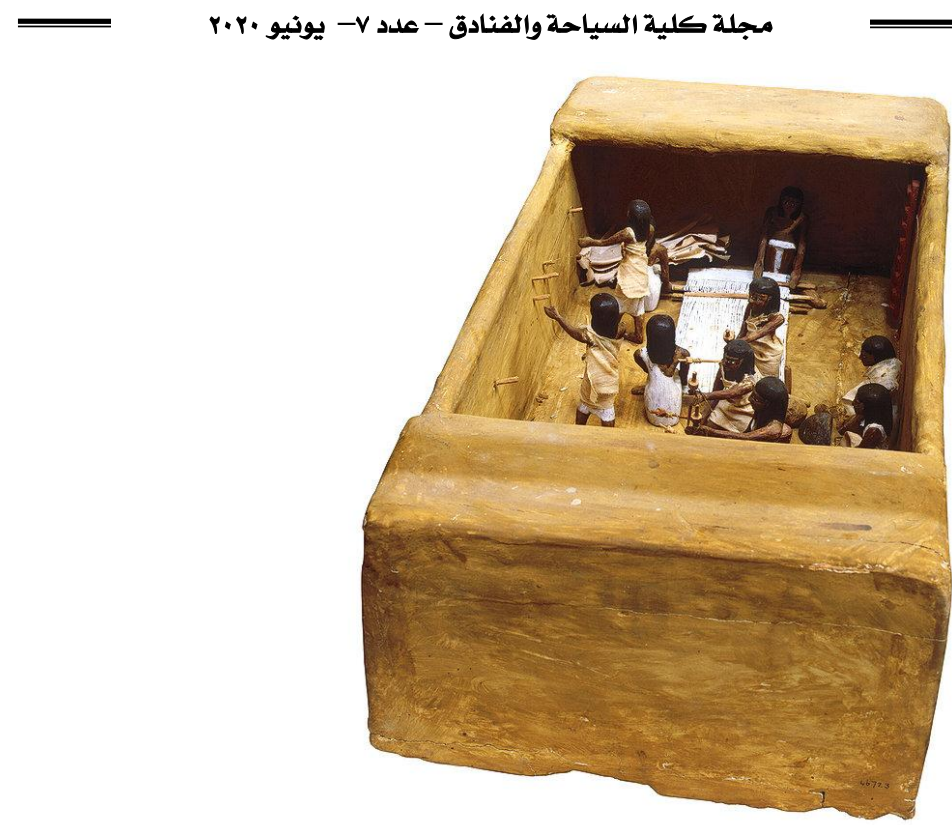

(Fig. 1) Model of a weavers' workshop from the Meketre collection.19

\section{Variations of linen}

Linen would have been embroidered and even pleated. The pleating of garments required special equipment, pleating boards, to hold the fabric in place. This method resulted in remarkably sturdy pleats. Modern scholars from the 1990s have recreated the process with replica pleating boards and noted how the pleats were strong enough to withstand a modern steam iron. However, in ancient times, garments needed to be reset and pleated after every wash.20

Plain linen could be adapted in a variety of different ways that affected both its structure and external decoration. Four different kinds of weaves have been identified from the most basic tabby weave to the "warp patterned" weave that is most famously known in a belt-like assemblage known as the girdle of Ramses III.21 ( fig. 2) Interestingly, the author believes the girdle has a design of inverted signs of life ankh and water waves. Some weaves were reserved for high-profile individuals like 
royalty and officials while the simpler weaves were used throughout the classes. Beyond weaves, fringe could be added to the border of garments, as found in the tomb of Khaa TT 8, an architect of Amenhotep III.

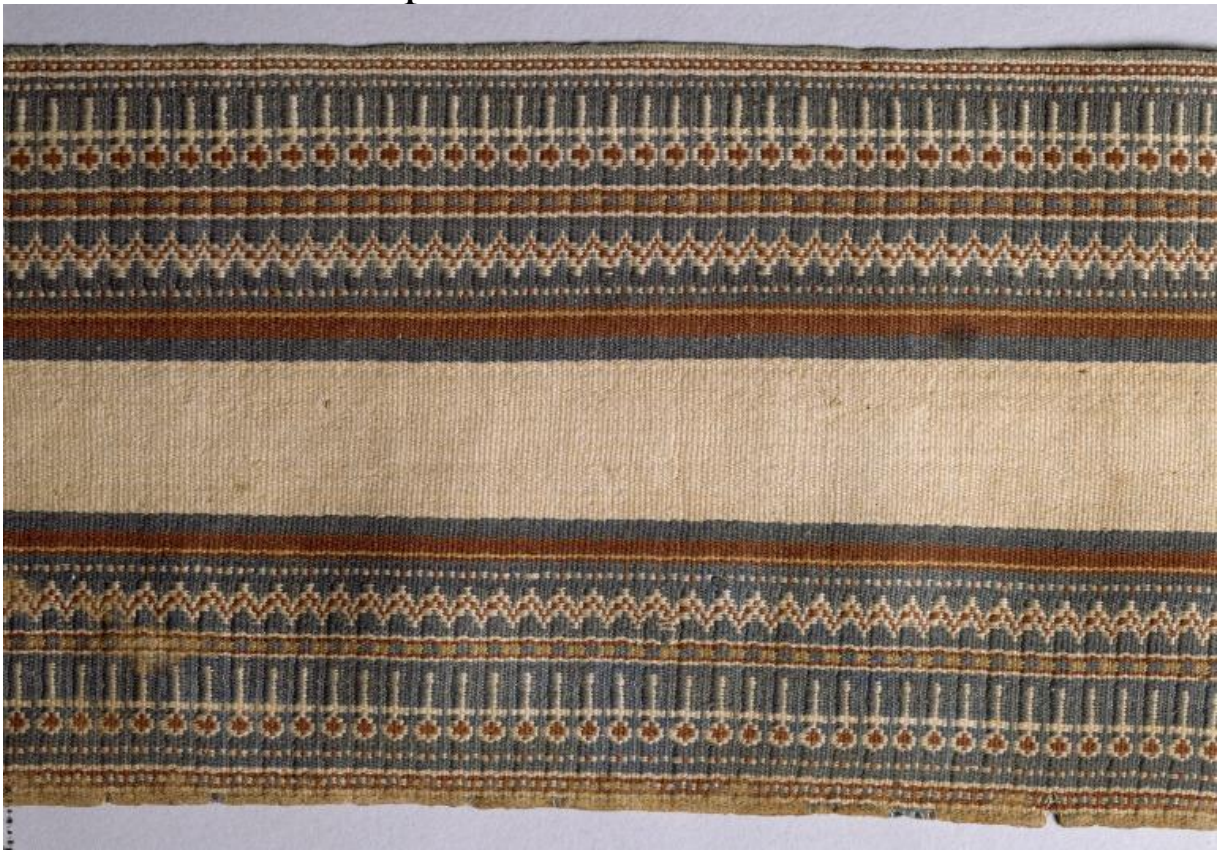

(Fig. 2) Ramses III's girdle.22

\section{Depictions of White linen fashion in tomb chapels}

There is a multitude of scenes depicting the popularity of white linen in the ancient Egyptian society. A striking example is the east wall, southern side of Nakht's offering chapel, TT52. (Plate 2) This scene originally dates back to approximately 1400 BCE. Nakht served as the scribe of the granaries in the royal court of Tuthmosis IV. The scene is compelling for its rich imagery, depicting an abundance of white linen worn by all human figures, except for one naked figure. (fig. 3) The tomb owner Nakht and his wife are represented on a larger scale overseeing a harvest scene split amongst two registers. The depiction of white linen is an essential aspect of this scene, in which both Nakht and his wife are represented in white.23 
Nakht's wife wears a long, body-hugging, one shoulder dress that is also translucent on one arm and above her ankles. (fig. 4) 24

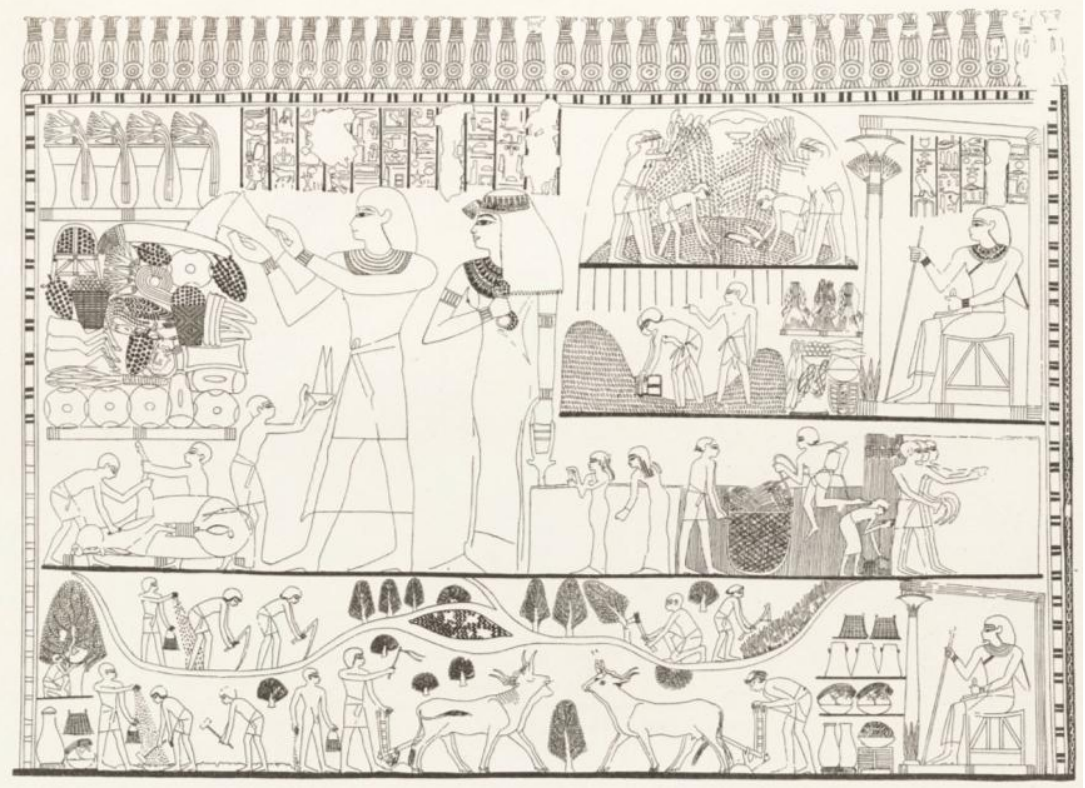

(Plate 2) Agricultural scenes of threshing, a grain store, harvesting with sickles, digging, tree-cutting and ploughing from the tomb of Nakht (TT 52) 18th Dynasty, western Thebes. 25

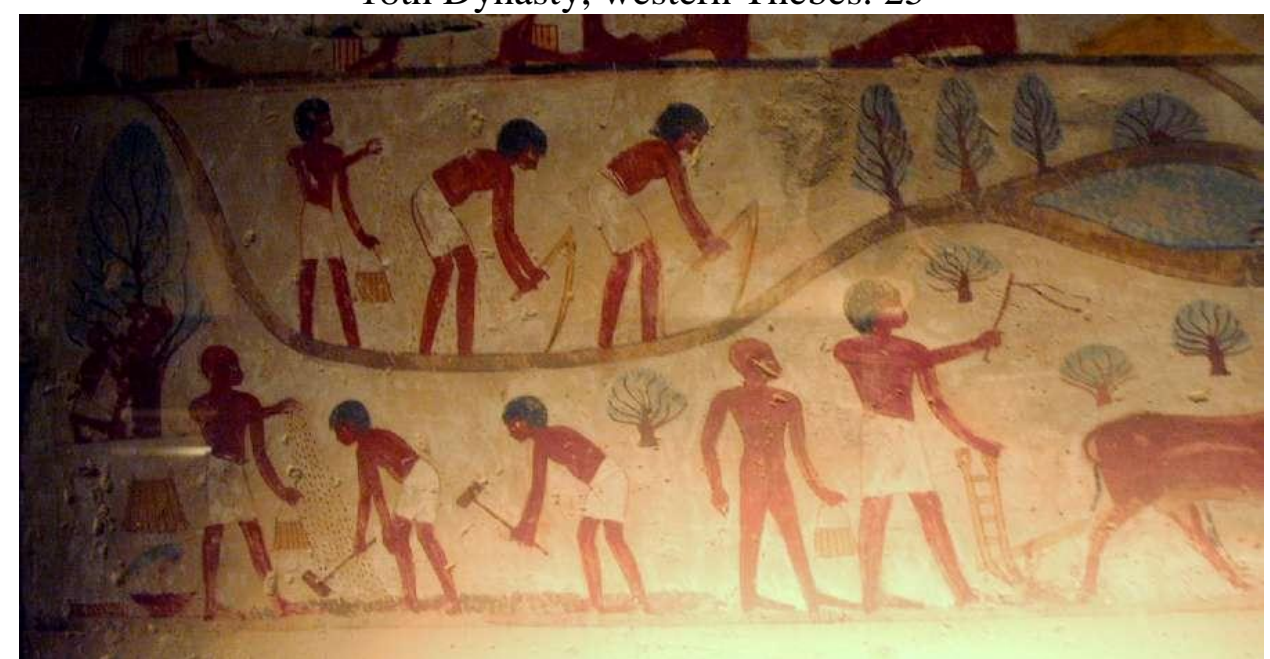

(Fig. 3) Details of the agricultural scene with men in kilts while one was represented naked (TT 52). 26 


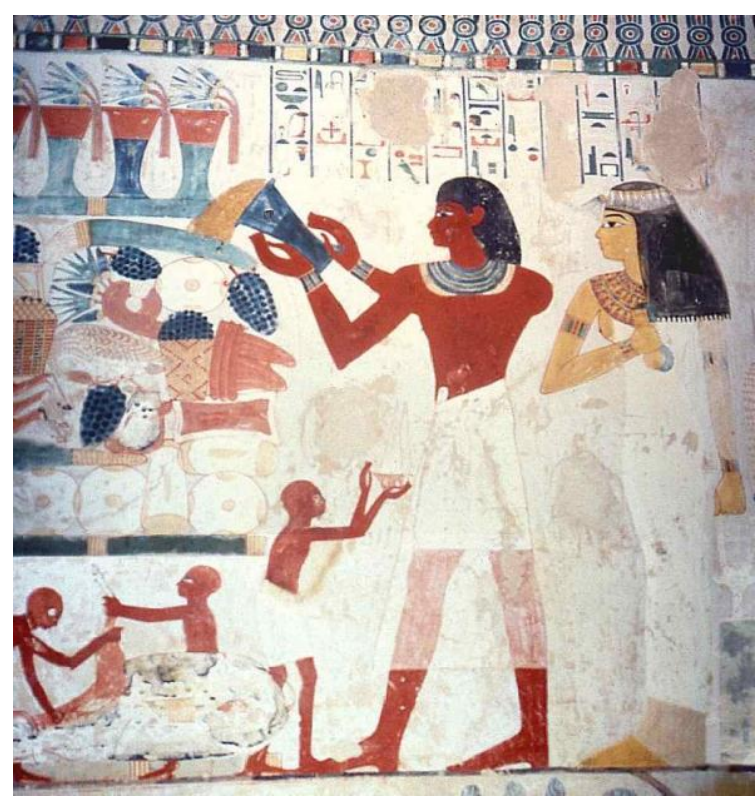

(Fig. 4) Nakht wears a long translucent drape showing his short kilt and the lower part of his legs. Whilst, his wife wears a long, tight, one shoulder dress reaching above her ankles while one arm has a translucent sleeve. 27

The lower register has a representation of two women harvesting flax; a job which was usually done by men. The men working in the fields were represented wearing different kinds of linen kilts. Some wear a knee-high kilt with a straight edge, while the rest of the men are also shown with kilts that have slits at the bottom resulting in a triangular form. While the women are represented wearing a similar dress to that of Nakht's wife except that the sleeve is not transparent (fig. 5). The transparency of clothing was very much popular during the New Kingdom times. 28 


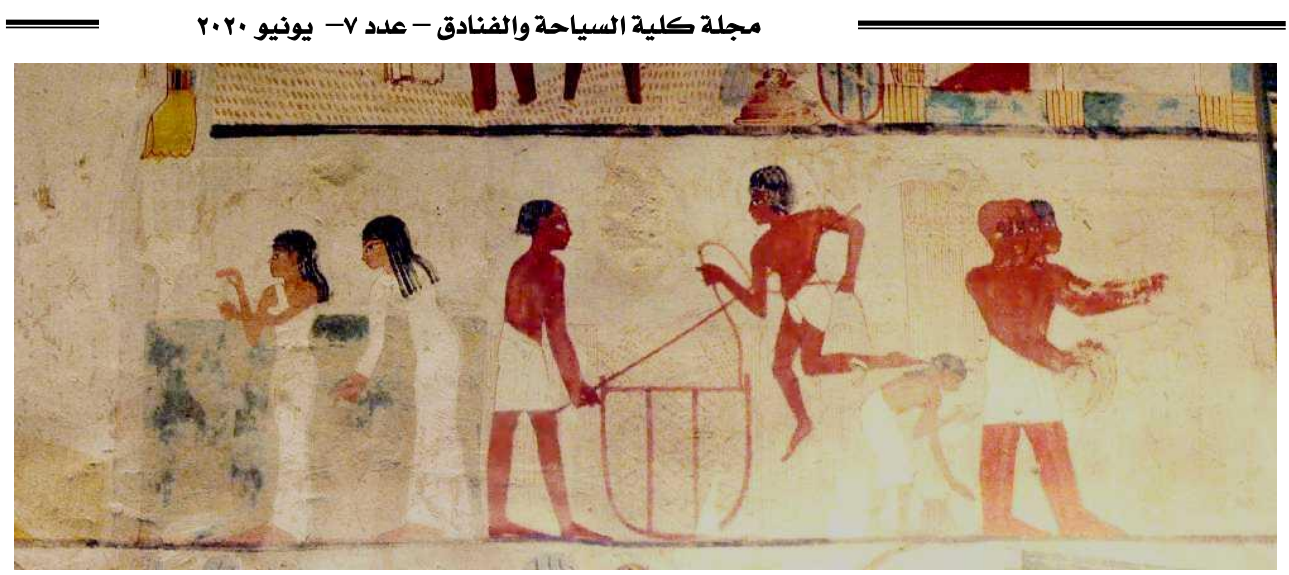

(Fig. 5) The women wear dresses, one of which wears the common strapped dress, whilst the other wears a long sleeve dress similar to Nakht's wife, however it is not translucent. 29

By the eighteenth dynasty new dress styles became popular, the most prominent style being the long, flowing, pleated linen dress.30 Later by the nineteenth dynasty, queen Nefertari wife of Ramses II is represented in her tomb (QV 66) at the Valley of the queens, she wears a white linen dress that is not at all form-fitting like, and her waist is emphasized by a long, red sash. The sleeves of Nefertari's dress are loose and flow outwards, joining in a triangular shape at the ends, near her elbows. There are notable pleats on the body and sleeves of the dress caused by the shading applied on the painting.

The 19th dynasty tomb of Sennedjem (TT 1), shows intricate pleating in both men and women's clothing. The top three registers of the east wall of the vaulted burial chamber have representations of different kinds of white linen clothing. Pleating was performed on the fabric while it was still damp. 31 The tailors quickly pressed the fabric into the serrated grooves of the pleating boards - two of which are on display in Turin. Rows of constant running stitches held the pleats in place during work on other sections of the garment, and the pressing was carried out with stones. The various poses of Sennedjem in the latter 
mentioned registers are mere proof of the garments' flexibility and comfort.

Most representations of ancient Egyptian clothing depict simple white garments. This is not necessarily inaccurate as the natural colour of linen varied from white to golden brown. 32 The strong desert sunlight would also likely lighten the darker natural shades of linen regardless. 33 Linen could also be bleached using natron, a naturally occurring mineral salt, to reach the whitest whites that are depicted in artistic examples. 34 The practice of dying fabrics existed from the predynastic era onwards, but it was uncommon and surviving dyed textiles are rare. 35 Additionally, no archaeological evidence of dye workshops nor models and paintings depicting the practice have been found. However, textiles found at the workmen's village at Amarna exists an exceedingly rare example of a double-dyed textile wherein the linen had been dyed one colour at an earlier stage in production, and later dyed a different colour to produce a mixture of two colours.36 As dyes were made from mineral substances or plant extracts, most archaeological examples of dyed textiles from ancient Egypt have aged poorly and turned dark with age. 37

\section{Adornment of Ancient Egyptian White Attire}

White linen cloth was paired with adornments of all different kinds so that the stark difference between the simple fabric and the ornate decoration complemented each other. Due to the environmental conditions at many burial sites - the humidity and heat - jewellery, amongst other artifacts, have been lucky to have outlived such weather conditions.38 Colourful waist sashes were sometimes adorned with religious symbols, such as the cow face of goddess Hathor, or by earthly motifs, such as the lotus flowers. The simple strapped tunic worn by most women was adorned by a web of bead netting worn over as an overdress (fig. 6). This bead net dress was either sewn onto a 
linen dress or worked into a separate net worn over the linen. It was discovered as part of the untouched burial of a female contemporary of King Khufu. The color of the beads has sadly faded, but the beads were originally of blue and blue green colours imitating lapis lazuli and turquoise. At other times, beads or buttons, which were never used to close openings, were sewn to the dress in pattern like formations.39

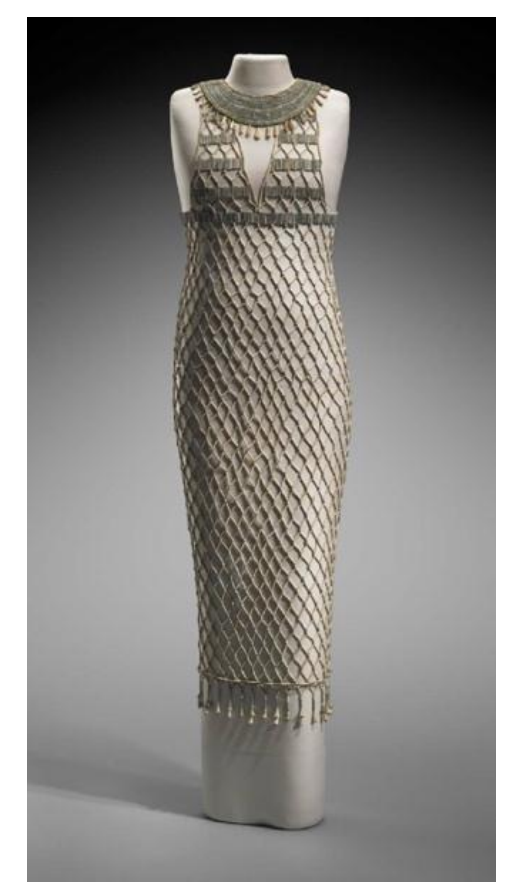

(Fig. 6) A bead net dress. 40

Jewellery of all kinds was key to adornment the ancient Egyptian white attire. Colourful accents took the form of necklaces, bracelets, armbands, ankle bands, earrings, and finger rings for both men and women. Arguably, the least subtle jewellery was that worn around the neck. Neck jewellery included single stranded necklaces, multiple strands, pectorals, pendants, some broad collars that were more than $25 \mathrm{~cm}$ wide. Neck jewellery (fig. 7) served for decorative purposes, as well as 
amuletic and status purposes. An example was the beautiful necklace of one of the three foreign wives of Tuthmosis III. On the back of the falcon-headed terminals is the name of King Tuthmosis inscribed demonstrating that it was a present to his wife. All the latter imagery was not possible to be represented within the use of white linen. Therefore, adornment in the form of jewellery was pivotal for making certain societal statements that were key in representing an individual's place in society. 41

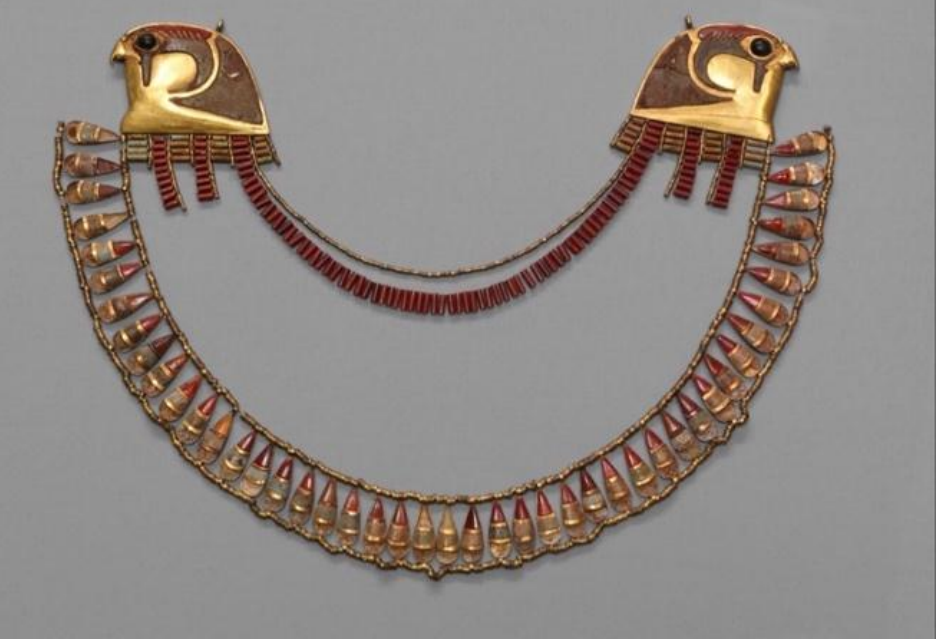

(Fig. 7) A falcon-headed terminals necklace belonging to Tuthmosis III's foreign wife. 42

Wealth was displayed through jewellery and not through clothing, except for the royal garments. Despite the riches gained from foreign conquests, tribute obtained from the defeated countries, and trade between foreign regions, Egyptian cloth was practically unadorned.43 The author believes that linen's central role was highlighted and brought to life by the vibrant adornments and complemented simplicity. However, the ornamentation of jewellery did not overshadow the importance of white line. White linen was depicted in paintings, reliefs, frescoes, leaving remnants behind in tombs, which left scholars some kind of archeological evidence. 


\section{Conclusion}

The varying artistic depictions of ancient Egyptian dresses reveal more to us in the present day than the aesthetic held across dynasties. The artistic evidence shows how the lives of the ancient Egyptian women, separated from our historical moment by thousands of years, valued their appearance not only for vanity's sake, but for the sake of continuing a shared cultural thread. The author appreciates how the concern for clothing unites the ancient women with the people, both men and women, in their aesthetic consciousness and care of reflecting oneself through their outer appearance. The latter was revealed in a New Kingdom funeral lament that reads "She who was rich in fine linen, who loved clothes, lies in the cast-off garment of yesterday." 44

The role of linen in ancient Egyptian society has been overshadowed by assumptions about Egypt, creating an image of lavish costumes in everyday life rather than focusing on the actual simplicity involved in ancient Egyptian dress. Clothing reflected the strictly hierarchical nature of the ancient Egyptian society and distinguished social rank. It was not the clothing that determined a person's social rank, it was the cloth to make them. The higher the person's rank, the better the cloth he or she could wear. Linen was worn by rulers and other high-status individuals - varying among different kinds of weaving.

White linen is a fascinating fabric as it highlights the beauty of simplicity and finesse, while also emphasizing the elegance of pairing lavish jewellery with plain clothing. However, artistically it exhibits self-expression through the use of jewellery, that would contrast with the simple and plain fabric of their clothing. Although it is undisputed that the ancient Egyptian society appreciated embellishment and adornment, it is essential to acknowledge the central role of white linen within the ancient society - during the everyday life, as well as their belief of their subsistence during the afterlife. 
Expressively enduring through the clothing statements of the Old Kingdom Nofret45, the Middle Kingdom Kemsit46, and the estate figure of an unknown body-figure from the New Kingdom Amarna, Nefertiti47 have all demonstrated, a woman in fine dress may be remembered and celebrated for millennia. As expressed, the material remains of women's dresses in ancient Egypt leave the author with a limited picture of what the female costume could have looked like throughout the kingdoms. Thus, an artistic analysis has proved itself indispensable.

\section{Endnotes}

${ }^{1}$ Green, L. 1995 -1996. "Seeing through Ancient Egyptian Clothes," KMT: A Modern Journal of Ancient Egypt 6,4; 28-40; 76,77.

${ }^{2}$ Cheryl, W., Patrick Couser, David Vann, Tom Vosmer, and Mohamed Abd El-Maguid, 2009. "Reconstruction and Sailing Performance of an Ancient Egyptian Ship," in N. Gu $\square$ nsenin(ed.), Proceedings of the 12th International Symposium on Boat and Ship Archaeology, Istanbul; 2.

${ }^{3}$ Catling, D. \& Grayson, J. 1982. Identification of Vegeatable Fibers, Chapman \& Hall, London \& N.Y.; 13.

${ }^{4}$ Hall, R. 1986. Egyptian Textiles. Shire Egyptology Series, 4. Princes Risborough, Bucks, England.

5 Foroughi. M, Javadi, S. 2017 "Examining the Symbolic Meaning of Colors in Ancient Egyptian Painting Art and Their Origin in Environment", Scientific journal of Nazar Research Center, for Art, Architecture \& Urbanism Bagh- e Nazar, 14 (52); 74.

${ }^{6}$ Brier, B., Hobbs, H. 2008. Daily life of the Ancient Egyptians. Malden, Blackwell; 104.

7 Janssen, R. M. H., 1995. "Costume in New Kingdom Egypt," in Civilizations of the Ancient Near East, ed. Jack M. Sasson et al. NY: Simon \& Schuster MacMillan; 383.

${ }^{8}$ Herodotus. 1942. Euterpe, ed. Francis Richard Borrum. New York: Random House; 96.

9 Janssen. 1995 "Costume in New Kingdom Egypt,"; 383.

${ }^{10}$ Contini, M. 1965. Fashion: From Ancient Egypt to the Present Day, ed. James Laver. New York, Odyssey Press; 23.

${ }^{11}$ Porter, B. \& Moss, R., 2004. Topographical bibliography of Ancient Egyptian hieroglyphic texts, reliefs and paintings, Second Edition, Vol. V, 
Upper Egypt sites, Griffith Institute, Ashmolean Museum, Oxford, 2004; 177-181.

${ }^{12}$ Elsharnouby, 2014. "Linen in Ancient Egypt"; 6.

${ }^{13}$ Tylor, J. J. \& Griffith, F.L., 1894. The tomb of Paheri at El kab, The Egypt Exploration Fund, 11; Plate No. 3.

${ }^{14}$ Watson, Philip J. 1987. Costume of Ancient Egypt. New York, Chelsea House; 9.

15 Nicholson, P. T., I. Shaw,2000. Ancient Egyptian Materials and Technology. Cambridge University; 43.

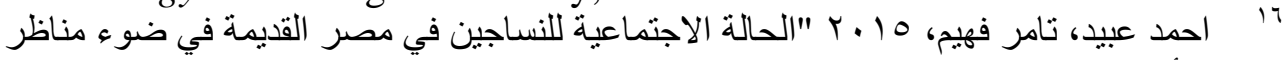
مقابر الأفر اد حتى نهاية الدولة الحديثة" مجلة كلية السياحة و الفنادق - جامعة الفيوم؛ المجئ المجلد التاسع

${ }^{17}$ Elsharnouby. 2014. "Linen in Ancient Egypt; 9.

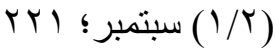

18 Janssen. 1995 "Costume in New Kingdom Egypt,"; 384.

$1911^{\text {th }}$ Dynasty wooden model originally exhibited on the upper floor, room 27 of the Cairo museum, JE 46723.

At the moment on temporary exhibit at the National museum of Egyptian Civilization. http://www.globalegyptianmuseum.org/record.aspx?id=15491

${ }^{20}$ Janssen. 1995 "Costume in New Kingdom Egypt,"; 385.

${ }^{21}$ Elsharnouby. 2014. "Linen in Ancient Egypt; 7.

22 http://www.liverpoolmuseums.org.uk/wml/collections/antiquities/ancientegypt/item-299418.aspx accessed July 2019. At the moment exhibited at the Egyptian Gallery at the World museum. For further reading Susan J Foulkes' 2009. "The Rameses Girdle - a weaving marvel", in The Journal for Weavers, Spinners and Dyers, vol. 230; 22-26.

${ }^{23} \mathrm{http} / / / \mathrm{www}$. metmuseum.org/art/collection/search/548438 accessed April 2019.

${ }^{24}$ Nakht wears a draped kilt that covers his lower body, and is translucent in the lowest part.

${ }^{25}$ Davies, Norman de Garis, 1917. "The Tomb of Nakht at Thebes", New York, MMA publications; 187.

26 Copyrights Chris Dispot. https://www.osirisnet.net/tombes/nobles/nakht52/e nakht 06.htm, accessed July 2019.

27 Copyrights Chris Dispot.

https://www.osirisnet.net/tombes/nobles/nakht52/e_nakht_06.htm, accessed July 2019. 
${ }_{29}^{28}$ Cosgrave, 2000. The Complete History; 17. Copyrights

Chris

Dispot.

https://www.osirisnet.net/tombes/nobles/nakht52/e_nakht_06.htm, accessed July 2019.

${ }^{30}$ Cosgrave, 2000. The Complete History; 15.

${ }^{31}$ Sennedjem wears a pleated costume.

32 Janssen. 1995 "Costume in New Kingdom Egypt,"; 385. 391.

${ }^{33}$ Watson, 1987. Costume of Ancient Egypt; 9.

${ }^{34}$ Janssen. 1995 "Costume in New Kingdom Egypt,"; 390.

${ }^{35}$ Nicholson, 2000. Ancient Egyptian Materials and Technology; 44.

${ }^{36}$ Elsharnouby. 2014. "Linen in Ancient Egypt; 10,12.

37 Janssen. 1995 "Costume in New Kingdom Egypt,"; 388.

${ }^{38}$ Cosgrave, 2000. The Complete History; 15.

${ }^{39}$ Brier. 2008. Daily life of Ancient Egyptians; 146.

${ }^{40}$ https://collections.mfa.org/objects/146531 accessed July 2019.

A $4^{\text {th }}$ Dynasty dress, reign of King Khufu; it was discovered in Giza, tomb G $7440 \mathrm{Z}$ in 1927 by the Harvard University-Museum of Fine Arts Expedition. At present it is in the Boston museum of fine arts, accession number 27.1548.1

${ }^{41}$ Brier. 2008. Daily life of Ancient Egyptians; 147, 149.

${ }^{42}$ https://www.metmuseum.org/art/collection/search/547636 accessed July 2019.

The 18th Dynasty collar is believed to have been discovered in western Thebes; at the moment it is on exhibit in the Metropolitan Museum of Arts, accession number 26.8.59a. For further reading Lilyquist, Christine 2003. The Tomb of Three Foreign Wives of Tuthmosis III. New York.

${ }^{43}$ Cosgrave, 2000. The Complete History; 20.

${ }^{44}$ Janssen. 1995 "Costume in New Kingdom Egypt,"; 386.

$454^{\text {th }}$ Dynasty statue presently on the ground floor, room 32 of the Cairo museum, CG 4.

${ }^{46} 11^{\text {th }}$ Dynasty sarcophagus presently on the upper floor, hall 48 of the Cairo museum, JE 47397.

${ }^{47} 18^{\text {th }}$ Dynasty unfinished head presently on the ground floor, room 3, JE 59286.

\section{Bibliography}

- Brier, B., Hobbs, H. 2008. Daily life of the Ancient Egypt. Malden, Blackwell. 
- https://www.brown.edu/Departments/Joukowsky_Institute/courses/introt oegypt13/files/25251720.pdf accessed April 2019.

- https://collections.mfa.org/objects/146531 accessed July 2019.

- Catling, D. \& Grayson, J. 1982. Identification of Vegeatable Fibers, Chapman \& Hall, London \& New York.

- Contini, M., 1965. Fashion: From Ancient Egypt to the Present Day, ed. James Laver. New York, Odyssey Press.

- Copyrights Chris Dispot.

https://www.osirisnet.net/tombes/nobles/nakht52/e_nakht_06.htm, accessed July 2019.

- Cosgrave, B., 2000. The Complete History of Costume and Fashion:

From Ancient Egypt to the Present day. London, Hamyln.

- Davies, Norman de Garis, 1917. "The Tomb of Nakht at Thebes", New York, MMA publications.

- Elsharnouby, R. A. M., 2014. "Linen in Ancient Egypt," Journal of General Union of Arab Archaeologists 15, no. 14.

- Foroughi. M, Javadi, S. 2017 "Examining the Symbolic Meaning of Colors in Ancient Egyptian Painting Art and Their Origin in Environment", Scientific journal of Nazar Research Center, for Art, Architecture \& Urbanism Bagh- e Nazar, 14 (52); 69-80.

- Green, L. 1995 -1996. "Seeing through Ancient Egyptian Clothes," KMT: A Modern Journal of Ancient Egypt 6,4; 28-40; 76,77.

- Hall, R. 1986. Egyptian Textiles. Shire Egyptology Series, 4. Princes Risborough, Bucks, England.

- Herodotus. 1942. Euterpe, ed. Francis Richard Borrum. New York: Random House.

- https://hiveminer.com/Tags/el\%2Ckab accessed April 2019.

- Janssen, Rosalind M. H. 1995 "Costume in New Kingdom Egypt," in Civilizations of the Ancient Near East, ed. Jack M. Sasson et al. NY: Simon \& Schuster MacMillan; 383-394.

- http://www.liverpoolmuseums.org.uk/wml/collections/antiquities/ancient -egypt/item-299418.aspx accessed July 2019

- http://www.metmuseum.org/art/collection/search/548438 accessed April 2019.

- https://www.metmuseum.org/art/collection/search/547636 accessed July 2019. 
- Nicholson, P. T. \& I. Shaw, 2000. Ancient Egyptian Materials and Technology. Cambridge University.

- https://www.brown.edu/Departments/Joukowsky_Institute/courses/introt oegypt13/files/25251720.pdf accessed May 2019.

- Porter, B. \& Moss, R., 2004. Topographical bibliography of Ancient Egyptian hieroglyphic texts, reliefs and paintings, Second Edition, Vol. V, Upper Egypt sites, Griffith Institute, Ashmolean Museum, Oxford, 2004; 177-181.

- Tylor, J. J. \& Griffith, F.L., 1894. The tomb of Paheri at El kab, The Egypt Exploration Fund, 11.

- Vogelsang-Eastwood G.M., 1992. The Production of linen in Pharaonic Egypt, Textile Research Centre, the National Museum of Ethnology, Leiden, 1992.

- Ward, C. Patrick Couser, David Vann, Tom Vosmer, \& Mohamed Abd El-Maguid, 2009. "Reconstruction and Sailing Performance of an Ancient Egyptian Ship," in N. Gu $\square$ nsenin(ed.), Proceedings of the 12th International Symposium on Boat and Ship Archaeology, Istanbul; 1-6.

- Watson, Philip J. 1987. Costume of Ancient Egypt. New York, Chelsea House.

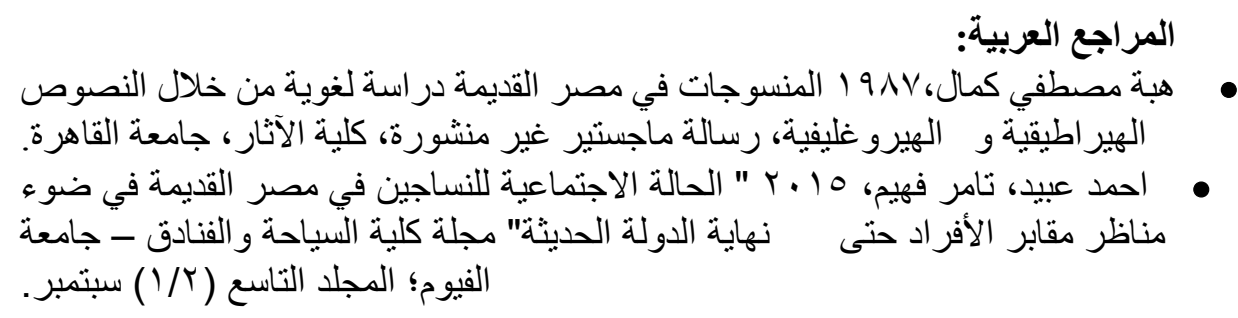

